\title{
Partai Politik dan Moderasi Beragama Sebagai Pilar Demokrasi di Indonesia
}

\author{
Muhammad Ardhi Razaq Abqa ${ }^{1}$
}

Universitas Tidar

\begin{abstract}
Indonesia is a large nation with a diversity and a lot of its society. In a multicultural society, there is a potential conflict among the nation's children who are at risk of splitting unity and unity. This kind of reality is often found in various democratic contestations in the election of regional chiefs (elections). Religious moderation becomes very important when in a process of democracies emerging identity politics which of course risk injuring democratic values. The purpose of this research to determine the moderation of religion as a pillar of democracy in Indonesia. The method used is research libraries. The conclusion of this research is the first, religious moderation is effective in establishing democratic elections, both political parties serve as a mobilizer for religious moderation to create a dignified and lasting democracy.
\end{abstract}

Keywords : Political Parties, Religious Moderation, Democracy

\begin{abstract}
Abstrak
Indonesia adalah bangsa yang besar dengan keanekaragaman dan kemajemukan masyarakatnya. Dalam masyarakat yang multikultural tersebut berpotensi terjadi konflik diantara anak bangsa yang beresiko memecah belah persatuan dan kesatuan. Realitas seperti ini sering ditemukan di berbagai kontestasi demokrasi yaitu dalam pemilihan kepala daerah (Pilkada). Moderasi beragama menjadi sangat penting ketika dalam suatu proses demokasi muncul politik identitas yang tentu saja beresiko mencederai nilai-nilai demokrasi. Tujuan penelitian ini untuk mengetahui moderasi beragama sebagai pilar demokrasi di Indonesia. Metode yang digunakan adalah penelitian pustaka. Kesimpulan penelitian ini adalah pertama, moderasi beragama efektif dalam mewujudkan Pilkada yang demokratis, kedua partai politik berfungsi sebagai penggerak moderasi beragama supaya tercipta demokrasi yang bermartabat dan berkeadaban.
\end{abstract}

Kata Kunci : Partai Politik, Moderasi Beragama, Demokrasi

\footnotetext{
${ }^{1}$ muhammadardhi@untidar.ac.id
} 


\section{Pendahuluan}

Indonesia menjadi salah satu negara di dunia yang memiliki beraneka ragam agama, budaya dan etnis yang tidak dimiliki oleh setiap negara. Keragaman tersebut dapat menjadi kekuatan sekaligus berpotensi tumbuhnya sikap fanatisme terhadap masing-masing golongan yang menyebabkan konflik antar anak bangsa. Masyarakat multikultural merupakan fitrah dari Tuhan YME yang harus dijaga dengan sebaik-baiknya. Tentu kondisi tersebut menjadi tugas kita semua bahwa kita harus bersikap toleransi terhadap perbedaan yang ada di masyarakat Indonesia. Merujuk kepada data Badan Pusat Statistik (BPS) tahun 2010, secara total terdapat 1331 jumlah suku dan sub suku, tahun 2013 (BPS) bekerja sama dengan Institute of Southeast Asian Studies (ISEAS) ditemukan 633 kelompok suku besar. ${ }^{2}$ Berkaitan dengan jumlah bahasa, Indonesia pada tahun 2017 tercatat memiliki 652 bahasa daerah yang tersebar di seluruh pelosok ${ }^{3}$. Kemudian berkaitan dengan agama, Indonesia memiliki enam agama besar yang dipeluk oleh masyarakatnya yakni agama islam, kristen, katholik, hindu, budha dan khonghucu. Namun lebih daripada itu di Indonesia masih banyak penganut kepercayaan leluhur. ${ }^{4}$ Realitas yang demikian dapat disimpulkan bahwa tantangan Indonesia kedepan sangat berat untuk menjaga kerukunan, keamanan dan kestabilan politik. Dalam perspektif agama, keragaman agama merupakan fitrah dari Tuhan YME, tentu kita sebagai hamba tidak dapat menolak ketika Tuhan sudah berkehendak, diciptakanlah beragam agama, suku, etnis supaya antar manusia bisa menjadi dinamis, saling belajar dan tumbuhnya toleransi antar umat beragama.

Dewasa ini intoleransi antar golongan yang ditemukan dalam potret beberapa kasus dalam proses demokrasi menjadi menarik dibahas, karena dalam perhelatan pemilihan kepala daerah (Pilkada) banyak sekali ditemukan politik identitas. Di Indonesia politik identitas telah lama menjadi topik pembicaraan di kalangan para ahli ilmu sosial. Clifford Geertz (1963) tulisan tentang "Primordial

\footnotetext{
${ }^{2}$ Kementerian Agama, Moderasi beragama, Badan Litbang dan Diklat Kementerian Agama RI, Jakarta, 2019, hlm. 2.

${ }^{3}$ Ibid., hlm. 3.

${ }^{4}$ Ibid., hlm. 3.
} 
Sentiment" mengatakan bahwa studi tentang politik identitas akan terus menjadi perhatian serius utamanya berkaitan dengan etnis, masyarakat pribumi (indigenous community) dan masyarakat lokal (local community).

Kasus politik identitas beberapa tahun yang lalu juga sempat menjadi keprihatinan semua pihak ketika berlangsung pemilihan kepala daaerah DKI Jakarta tahun 2017. Survei Populi Center setelah pilkada DKI Jakarta putaran pertama, ditemukan bahwa isu sara dipergunakan untuk alat kampanye supaya memilih calon gubernur muslim dan masalah lainnya yaitu tidak akan disholatkan jenazah yang memilih calon gubernur non muslim, kondisi tersebut tentu membuat masyarakat yang mempunyai hak politik untuk berpartisipasi dalam proses demokrasi merasa terintimidasi. $^{5}$

Demokrasi sendiri merupakan bentuk pemerintahan yang kebijakannya dipengaruhi oleh suara mayoritas masyarakat yang memiliki hak suara melalui wadah pemilihan. ${ }^{6}$ Joseph Schumpeter mengatakan bahwa demokrasi juga bisa definisikan yaitu pertama, kehendak dari rakyat, karena demokrasi merupakan pemerintahan dari rakyat, oleh rakyat dan untuk rakyat. Kedua, demokrasi sebagai kebaikan bersama (common good), tujuan sistem pemerintahan demokratis yaitu menghadirkan kebaikan bersama dilaksanakan melalui kontrak politik. ${ }^{7}$ Sehingga menurut Carter dan Herz demokrasi setidaknya memiliki beberapa karakteristik, pertama, dalam pemerintahan harus ada pergantian pemerintahan, kedua, adanya sikap toleran terhadap pendapat kelompok yang berlawanan, ketiga, persamaan dihadapan hukum (equality before the law) diaplikasikan dengan sikap patuh kepada supremasi hukum, keempat, adanya pemilihan yang bebas tanpa intimidasi dan disertai dengan sistem perwakilan yang efektif, kelima, diberikannya ruang bagi partai politik peserta pemilihan termasuk juga organisasi kemasyarakatan (interest group) serta kelompok penekan (pressure group), keenam, adanya penghormatan

\footnotetext{
${ }_{6}^{5}$ https://www.bbc.com/indonesia/indonesia-39372353 diakses pada 2 April 2020.

${ }^{6}$ Leo Agustino, Pilkada Dan Dinamika Politik Lokal, Pustaka Pelajar, 2009, hlm. 39.

${ }^{7}$ Ibid., hlm. 40.
} 
kepada hak asasi manusia berkaitan dengan menyatakan pandangan atau pendapatnya, ketujuh, mengakomodir dan menghargai hak-hak kaum minoritas. ${ }^{8}$

Sehingga ketika tujuh karakteristik demokrasi itu dapat berjalan dengan efektif seharusnya proses pilkada yang menjadi instrumen demokrasi dapat berjalan dengan baik, bermartabat dan berkeadaban tanpa adanya politik identitas yang justru merusak cita dan tujuan besar bangsa Indonesia yaitu tegaknya pancasila. Keberadaan partai politik juga menjadi penting karena bagian dari pilar demokrasi, partai politik pada hakikatnya merupakan manifesto dari kebebasan masyarakat untuk membentuk kelompok sesuai dengan kepentingannya, oleh sebab itu bisa disimpulkan bahwa kebebasan berserikat adalah kebebasan yang diakui secara universal dan kemudian dikenal sebagai kemerdekaan beserikat (freedom of association). ${ }^{9}$ Richard H. Pildes dengan bahasa lain menyebutkan bawah tanpa adanya kemerdekaan berserikat maka harkat dan martabat kemanusiaannya dapat berkurang karena seseorang tidak dapat mengekspresikan keyakinan dan hati nuraninya. ${ }^{10}$ Sehingga dapat disimpulkan bahwa demokrasi dan partai politik mejunjung tinggi hak asasi manusia warga negaranya tanpa adanya intimidasi dan politik identitas yang menjadi persoalan serius dalam pergulatan politik di Indonesia.

Supaya tidak terjadi pelebaran pembahasan sebagaimana penulis uraikan diatas maka penelitian ini di fokuskan pada pembahasan dua hal yang perlu didiskusikan lebih lanjut yaitu:

1. Bagaimana efektifitas moderasi beragama dalam mewujudkan pemilihan kepala daerah (Pilkada) yang demokratis?

2. Bagaimana fungsi partai politik dalam moderasi beragama sebagai pilar demokrasi?

\footnotetext{
${ }^{8}$ Ibid., hlm. 41-42

${ }_{9}$ Muhaddam Labolo Dan Teguh Ilham, Partai Politik Dan Sistem Pemilihan Umum Di Indonesia (Teori Konsep Dan Isu Strategis), PT RajaGrafindo Persada, Jakarta, 2015, hlm 8

${ }^{10}$ Ibid.,
} 


\section{Metode Penelitian}

Penelitian ini adalah penelitian deskriptif menggunakan pendekatan kualitatif melalui metode pengumpulan data library research. Data-data dalam penelitian diambil dari sumber kedua, yaitu dari sumber buku-buku, e-book, jurnal ilmiah, hasil penelitian, artikel dan opini media cetak lokal yang ada di Indonesia. Yang diambil melalui website dan sumber dokumen tertulis lainnya, yang bisa dijadikan sebagai sumber informasi dan data untuk bisa dianalisis dalam penelitian ini.

\section{Hasil dan Pembahasan}

\section{Efektifitas Moderasi Beragama Dalam Mewujudkan Pemilihan Kepala Daerah (Pilkada) Yang Demokratis}

Pengetahuan dalam ajaran setiap agama sangat penting bagi para pemeluknya. Pengetahuan atas dasar keragaman menjadi jembatan seseorang untuk memeluk agama dengan mengambil jalan tengah (moderat) apabila seseorang hanya memilih satu tafsir yang diyakini maka pada gilirannya akan sampai pada sikap ekstremisme karena tidak mengetahui adanya alternatif kebenaran tafsir yang lainnya. Dalam konteks inilah kemudian moderasi beragama menjadi sangat penting dijadikan sebuah cara pandang (perspektif) dalam beragama. ${ }^{11}$ Dalam upaya menangkal gerakan ekstremisme, moderasi beragama sangat penting dalam sebuah negara. Bangsa yang besar dengan tingkat kemajemukan yang sangat multikultural perlu waspada dengan berbagai ancaman konflik antar golongan.

Konflik agama sering terjadi di berbagai kelompok dalam satu agama yang sama (sektarian atau intra agama) dan dapat pula terjadi pada kelompok dalam agama yang berbeda-beda (komunal atau antar agama), kedua konflik tersebut bisa terjadi akibat sikap saling menyalahkan tafsir dan pemahaman yang merasa benar sendiri dan tidak mencoba membuka diri pada tafsir dan pandangan keagamaan yang lainnya. $^{12}$

\footnotetext{
${ }_{11}^{11}$ Op.Cit., Kementerian Agama, Moderasi beragama..., hlm. 5.

${ }^{12}$ Ibid., hlm. 6
} 
Moderasi beragama sebagai spirit untuk mencari titik temu dua kutub ekstrem dalam beragama. Pemeluk agama yang ekstrem menyakini mutlak bahwa kebenaran satu tafsir teks agama, selain itu mereka juga menganggap sesat tafsiran dari kelompok lain, sehingga kelompok ini dikenal dengan ultra-konservatif. Di pihak lain ada kelompok ekstrem yang mendewakan akal sehingga mengabaikan kesucian agama atau mengorbankan kepercayaan dasar ajaran agamanya demi toleransi yang tidak pada tempatnya kepada pemeluk agama yang lain, mereka dikenal dengan sebutan ekstrem liberal. ${ }^{13}$

Mengulas lebih dalam tentang asal istilah moderasi beragama, kata moderasi berasal dari bahasa latin 'moderatio' yang mempunyai makna tidak berlebihan dan tidak kurang (sedang). Dalam KBBI moderasi bisa diartikan; pengurangan kekerasan dan penghindaran keekstreman, jadi apabila ada seseorang yang disebut moderat maka dimaknai orang tersebut bersikap wajar, biasa saja dan tidak ekstrem. Dalam bahasa inggris, istilah moderation sering digunakan dalam arti average (rata-rata), core (inti), standard (baku), atau non aligned (tidak berpihak) sehingga secara umum, moderat berarti mengutamakan keseimbangan (balances) dalam keyakinan, moral dan watak baik ketika memperlakukan orang lain sebagai individu maupun sebagai institusi negara. Lebih dari itu dalam bahasa arab moderasi dikenal dengan kata wasath atau wasathiyah, asal kata dari tawassuth (tengah-tengah), i'tidal (adil) dan tawazun (berimbang). Seseorang yang berprinsip wasathiyah bisa disebut wasith. ${ }^{14}$ Jadi moderasi beragama dapat disimpulkan sebagai sikap yang seimbang antara pengamalan agama sendiri (eksklusif) dan penghormatan terhadap perbedaan keyakinan orang lain dalam praktik beragama (inklusif).

Dalam konteks pemilihan kepala daerah (Pilkada) tidak sedikit yang berujung konflik berkepanjangan akibat kerasnya persaingan dan adanya politik identitas agama yang coba dilancarkan oleh oknum-oknum tidak bertanggung jawab. Sejatinya kontestasi Pilkada merupakan representasi dari kedaulatan rakyat, sehingga esensi diselenggarakannya Pilkada untuk mencari pemimpin yang

\footnotetext{
${ }^{13}$ Ibid., hlm. 7

${ }^{14}$ Ibid., hlm. 15-16.
} 
dianggap mempunyai integritas serta mempunyai kompetensi untuk menjalankan gagasan-gagasan selama kampanye bukan dipilih atas dasar persamaan etnis, suku dan agama.

Konflik dalam Pilkada sangat mengganggu jalannya proses demokrasi di tingkat daerah. Aksi pengepungan dan pengrusakan kantor KPUD, bentrokan dengan petugas keamanan, benturan antara pendukung calon kandidat dan banyak lagi yang terjadi di beberapa daerah menunjukkan bahwa masyarakat belum dewasa dalam politik. Padahal para ahli bidang politik di antaranya Huntington (1991) serta Linz dan Stepan (1996) mempunyai pandangan bahwa suatu negara dikatakan demokratis ketika memiliki indikator yaitu, pertama, memiliki kebebasan kepada masyarakat untuk merumuskan preferensi-preferensi politik mereka melalui jalur perserikatan, informasi dan komunikasi, kedua, memberikan ruang berkompetisi yang sehat dan melalui cara-cara damai dan, ketiga, tidak melarang siapapun berkompetisi untuk jabatan politik. ${ }^{15}$

Dalam perhelatan beberapa kali Pilkada selama berlangsung setidaknya ada lima sumber konflik potensial dimulai dari menjelang, ketika penyelenggaraan, serta sampai pada pengumuman hasil Pilkada, pertama, konflik bersumber pada mobilisasi politik atas dasar etnis, agama, wilayah dan darah. Sumber konflik pertama tersebut berpotensi terjadi di wilayah-wilayah yang ketegangan etnis dan agama cenderung tinggi yaitu seperti Kalimantan, Sulawesi, dan Maluku. Kedua, konflik yang bersumber pada kampanye negatif (black campaign) antara pasangan calon kepala daerah. Sehingga kampanye negatif yang menghadirkan fitnah mengenai integritas kandidat bisa beresiko menciptakan konflik antara massa pendukung dalam kampanye Pilkada. Ketiga, konflik yang didasarkan atas premanisme politik dan pemaksaan kehendak. Realitas ini terjadi dengan dibuktikan dengan gejala-gejala yang ditemukan seperti massa pendukung memprotes KPUD karena calon yang mereka usung tidak lolos administratif, kemudian pasca pengumuman pemenang Pilkada, sering terjadi pengepungan KPUD dengan dibarengi pengarahan massa dan tindak kekerasan dengan alasan terjadi kecurangan

\footnotetext{
${ }^{15}$ Op,Cit., Leo Agustino, Pilkada Dan Dinamika, hlm. 150
} 
dalam penghitungan suara. Keempat, konflik Pilkada yang bersumber dari pengerahan birokrasi oleh calon petahana (incumbent) dengan memanfaatkan sumber daya yang dimiliki untuk menekan pemilih untuk memilih calon petahana tersebut. Netralitas birokrat (PNS, TNI, Polri) menjadi penting supaya demokrasi tetap terjaga. Kelima, adanya penafsiran berbeda-beda terkait aturan penyelenggaraan Pilkada seperti undang-undang, peraturan pemerintah dan peraturan lainnya. ${ }^{16}$ Dari paparan sumber konflik tersebut maka sudah tentu proses demokrasi di suatu negara berpotensi mengalami kemerosotan yang tajam, kedewasaan dalam berpolitik juga tampaknya sangat menentukan dalam berkonstribusi menjaga kestabilan politik di tingkat nasional.

Atma Jaya Institute Of Public Policy dalam pemaparannya sebanyak 60 persen kaum muda perkotaan di Jabodetabek, Bandung, dan Surabaya berpendapat bahwa kualitas demokrasi di Indonesia buruk dan mereka menganggap bahwa politisasi agama menjadi alasan utama yang mempengaruhi kualiatas demokrasi. Kemudian lebih lanjut dalam pemaparannya politisasi agama menjadi yang nomor satu dengan 45 persen, hoax (berita bohong) 22 persen, korupsi 17 persen dan radikalisme 11 persen. ${ }^{17}$ Lembaga ilmu pengetahuan Indonesia (LIPI) juga melakukan survei dalam pemaparannya sebanyak 55,2 persen responden menyatakan bahwa kondisi toleransi selama 5 tahun terakhir adalah yang terburuk, sedangkan 7,6 persen responden menilai sangat buruk. ${ }^{18}$

Kesimpulan dari dua lembaga survei tersebut menempatkan persoalan politisasi agama dan kemerosotan sikap toleransi pada urutan pertama, sehingga moderasi beragama di Indonesia harus konsisten disosialisasikan oleh seluruh elemen bangsa, bahwa prinsip demokrasi dalam ancaman ketika politik identitas sangat kentara di dalam perkembangan politik nasional. Adapun prinsip-prinsip demokrasi sebagaimana telah diakomodir dalam konstitusi Negara Kesatuan Republik Indonesia (NKRI) yaitu adanya pluralisme dan nilai-nilai toleransi.

\footnotetext{
${ }^{16}$ Ibid., hlm. 150-152.

${ }^{17}$ https://nasional.tempo.co/read/1180478/survei-atma-jaya-sebut-politisasi-agama-perburukdemokrasi diakses tanggal 5 April 2020

${ }^{18}$ https://kabar24.bisnis.com/read/20180807/15/825285/survei-lipi-politisasi-sara-ancamdemokrasi diakses tanggal 5 April 2020
} 
Dengan demikian untuk menangkal segala konflik di dalam proses demokrasi yang sudah penulis uraikan diatas, maka penulis berpendapat bahwa moderasi beragama sangat efektif dalam mewujudkan Pilkada yang demokratis, karena moderasi beragama sendiri meniscayakan umat beragama untuk tidak bersikap ekslusif (tertutup) melainkan bersikap inklusif (terbuka), sehingga moderasi beragama dapat menjadi sarana untuk tidak bersifat ekstrem dan berlebihan dalam menyikapi perbedaan dalam pilihan politik melainkan harus tetap menghormati pilihan politik masing-masing tanpa mengintimidasi seseorang dengan dalih karena tidak sepaham dengan pilihan politik golongannya.

\section{Fungsi Partai Politik Dalam Moderasi Beragama Sebagai Pilar Demokrasi}

Partai politik merupakan komponen infrastruktur politik, karena strukturnya berada di bawah permukaan yaitu ada pada masyarakat. Partai politik pada prinsipnya yaitu suatu kelompok yang terorganiser yang mempunyai tujuan yang sama yaitu meraih kekuasaan politik. Menurut Carl J. Friederich, partai politik dikatakan sebagai sekelompok manusia yang terorganiser secara stabil dengan tujuan untuk merebut atau mempertahankan kekuasaan untuk diberikan kepada anggota berupa kemanfaatan yang bersifat idiil maupun materil. Kemudian dalam bahasa lain yang sedikit berbeda R.H Soltau mengemukakan bahwa partai politik adalah sekelompok warga negara yang sedikit banyak terorganiser, sebagai suatu kesatuan politik dengan tujuan menguasai pemerintahan dan melaksanakan kebijaksanaan umum. ${ }^{19}$

Kemudian dalam Undang-Undang Republik Indonesia Nomor 2 Tahun 2011 tentang partai politik, definisi "partai politik adalah sebagai organisasi yang bersifat nasional dan dibentuk oleh sekelompok warga negara Indonesia secara sukarela atas dasar kesamaan kehendak dan cita-cita untuk memperjuangkan dan membela kepentingan politik anggota, masyarakat, bangsa dan negara, serta memelihara keutuhan Negara Kesatuan Republik Indonesia berdasarkan Pancasila

\footnotetext{
${ }^{19}$ I Gede Yusa dkk, Hukum Tata Negara (Pasca Perubahan UUD NRI 1945), Setara Pers, Malang, 2016, hlm. 218
} 
dan Undang-Undang Dasar Negara Republik Indonesia Tahun 1945". ${ }^{20}$ Sehingga bisa disimpulkan bahwa partai politik pada intinya merupakan sekelompok yang terorganiser untuk mencapai tujuan meraih kekuasaan secara konstitusional.

Partai politik mempunyai posisi (status) dan peranan (role) yang sangat penting dalam sistem demokrasi bahkan para ahli berpendapat bahwa partai politiklah yang sebetulnya memegang kendali dalam menentukan jalannya demokrasi. Schattscheider (1942), berpendapat "political parties created democracy". Dengan demikian partai politik merupakan pilar penting dalam demokrasi. $^{21}$

Partai politik dalam kegiatan bernegara juga memiliki peran sebagai media dan wahana yang tentu sangat sentral peranannya. Partai politik juga sangat berperan dalam dinamika perjuangan nilai dan kepentingan (values and interests) dari konstituen yang diwakilinya untuk menentukan kebijakan dalam konteks bernegara. Kesempatan sukses dalam setiap memperjuangkan kepentingan sangat ditentukan dari tingkat kebersamaan dalam organisasi. Dengan demikian organisasilah menjadi syarat mutlak dan hakiki bagi setiap perjuangan politik (organizational imperative). ${ }^{22}$

Secara pragmatis, tujuan partai politik tidak lain orientasinya adalah kekuasaan, kondisi tersebut ketika berkuasa dalam pemerintahan maka ideologi, visi dan misi, program partai politik dapat digunakan sebagai landasan untuk menjalankan kekuasaan yang pada gilirannya partai politik memperoleh kemanfaatan. Dengan melihat aktifitas dari partai politik, rakyat sebagai subyek dalam sistem ketatanegaraan mempunyai pilihan-pilihan alternatif, yakni partai politik mana yang akan dijadikan saluran politik atau kendaraan politik mereka dan mana yang akan diikuti. Struktur masyarakat yang masih paternalistik (membatasi kebebasan) dalam perjalanannya rakyat akan memilih untuk berafiliasi kepada partai tertentu masih dipengaruhi oleh tokoh-tokoh politik tersebut. Bahkan tidak sedikit afiliasi tersebut dipengaruhi oleh ideologi. Kemudian struktur masyarakat

${ }^{20}$ Ibid., hlm. 220

21 Jimly Asshiddiqie, Pengantar Ilmu Hukum Tata Negara, Sekretariat Jenderal Dan Kepaniteraan Mahkamah Konstitusi RI, Jakarta, 2006, hlm. 153.

${ }^{22}$ Ibid., hlm. 155. 
yang bersifat primordial paternalistik sering dimanfaatkan oleh partai politik untuk meraih sebanyak-banyaknya dukungan rakyat. Kondisi demikian ikatan emosional antara rakyat dengan ideologi yang dibawa oleh para tokoh politik relatif kuat. ${ }^{23}$

Dengan demikian partai politik dapat mempengaruhi rakyat secara efektif, baik buruknya kualitas demokrasi juga dipengaruhi oleh bagaimana fungsi dari partai politik itu sendiri maka partai politik mempunyai peran sentral dalam penggerak moderasi beragama sebagai pilar demokrasi. Sudah saatnya partai politik berperan aktif tidak hanya menjalankan fungsi regulernya ${ }^{24}$ (fungsi komunikasi politik, fungsi sosialisasi politik, fungsi rekruitmen politik dan fungsi pengatur konflik). Oleh sebab itu penulis berpendapat bahwa dalam mengatasi politik identitas yang terjadi dewasa ini partai politik hadir sebagai kekuatan penggerak moderasi beragama, setidaknya penulis memberikan lima sumbangan pemikiran sebagai ikhtiar dalam moderasi beragama yang dilakukan partai politik, langkah pertama, partai politik senantiasa menjunjung tinggi dasar negara yaitu Pancasila dan konstitusi UUD NRI 1945 dan selalu mensosialisasikan kepada para pendukungnya. Kedua, partai politik harus menjadi garda terdepan dalam memberikan pendidikan politik yang baik. Ketiga, dalam pemilihan kepala daerah (Pilkada) partai politik mempunyai spirit untuk berkampanye dengan damai dan sportif menonjolkan gagasan calon kepala daerahnya, keempat, partai politik sebagai pelopor pencegahan kampanye hitam dan berita bohong (hoax), dan kelima, di dalam internal partai politik perlu memasukkan nilai-nilai agama yang moderat untuk bersikap (inklusif) terbuka menghormati perbedaan, serta menghindari sikap (ekslusifisme).

${ }^{23}$ Hestu Cipto Handoyo, Hukum Tata Negara Indonesia (Menuju Konsolidasi Sistem Demokrasi), Universitas Atma Jaya Yogyakarta, Yogyakarta, 2009, hlm, 263

${ }^{24}$ Op. Cit., Jimly Asshiddiqie, Pengantar Ilmu Hukum..., hlm. 159. 


\section{Kesimpulan}

Efektifitas moderasi beragama dapat mewujudkan pemilihan kepala daerah yang demokratis ketika semua elemen bangsa mempunyai kesadaran atas dasar persamaan cita-cita bersama dalam mewujudkan demokrasi yang bermartabat dan berkeadaban. Politik identitas bisa diberantas dengan ikhtiar moderasi beragama yang menekankan kepada keseimbangan antara inklusif dan ekslusif. Partai politik salah satu sarana sebagai penggerak moderasi beragama, karena partai politik merupakan pilar demokrasi sekaligus infrastruktur politik yang ada di dalam masyarakat sehingga politik identitas bisa dicegah melalui beberapa langkah partai politik yang sangat efektif mempengaruhi konstituen, partai politik diharapkan tetap menjunjung tinggi Pancasila dan UUD NRI 1945.

\section{Daftar Pustaka}

Agustino, Leo. 2009. Pilkada Dan Dinamika Politik Lokal. Yogyakarta: Pustaka Pelajar

Asshiddiqie, Jimly. 2006. Pengantar Ilmu Hukum Tata Negara, Sekretariat Jenderal Dan Kepaniteraan Mahkamah Konstitusi RI. Jakarta

Buchari, Sri Astuti. 2014. Kebangkitan Etnis Menuju Politik Identitas. Jakarta: Yayasan Pustaka Obor Indonesia

Handoyo, Hestu Cipto. Hukum Tata Negara Indonesia (Menuju Konsolidasi Sistem Demokrasi). Yogyakarta: Universitas Atma Jaya Yogyakarta.

https://kabar24.bisnis.com/read/20180807/15/825285/survei-lipi-politisasi-saraancam-demokrasi

https://nasional.tempo.co/read/1180478/survei-atma-jaya-sebut-politisasi-agamaperburuk-demokrasi

https://www.bbc.com/indonesia/indonesia-39372353

Kementerian Agama. 2019. Moderasi beragama, Badan Litbang dan Diklat Kementerian Agama RI. Jakarta,

Labolo, Muhaddam dan Ilham, Teguh. 2005. Partai Politik Dan Sistem Pemilihan Umum Di Indonesia (Teori Konsep Dan Isu Strategis). Jakarta: PT RajaGrafindo Persada

Yusa, I Gede; dkk. 2016. Hukum Tata Negara (Pasca Perubahan UUD NRI 1945). Malang: Setara Pers. 